\title{
Leadership After Virtue: MacIntyre's Critique of Management Reconsidered
}

\author{
Matthew Sinnicks ${ }^{1}[$
}

Received: 1 December 2015 / Accepted: 6 November 2016/Published online: 29 November 2016

(C) The Author(s) 2016. This article is published with open access at Springerlink.com

\begin{abstract}
MacIntyre argues that management embodies emotivism, and thus is inherently amoral and manipulative. His claim that management is necessarily Weberian is, at best, outdated, and the notion that management aims to be neutral and value free is incorrect. However, new forms of management, and in particular the increased emphasis on leadership which emerged after MacIntyre's critique was published, tend to support his central charge. Indeed, charismatic and transformational forms of leadership seem to embody emotivism to a greater degree than do more Weberian, bureaucratic forms of management; hence, MacIntyre's central contention about our emotivistic culture seems to be well founded. Having criticised the details but defended the essence of MacIntyre's critique of management, this paper sketches a MacIntyrean approach to management and leadership by highlighting the affinities between MacIntyre's political philosophy and Greenleaf's concept of servant leadership.
\end{abstract}

Keywords Management history · Emotivism - Alasdair MacIntyre · Virtue ethics · Charismatic leadership · Servant leadership

\section{Introduction}

MacIntyre has been cited in the business ethics literature more frequently than any other living virtue ethicist (Ferrero and Sison 2014). Most of the business ethics scholarship informed by MacIntyre has focused on his 'goods-

Matthew Sinnicks

matthewsinnicks@yahoo.co.uk

1 Northumbria University, Newcastle upon Tyne, UK practices-institutions' framework as it relates to business ethics, but this paper focuses instead on his other contribution to business ethics-his critique of management. Numerous scholars have sought to challenge this critique (for example, Brewer 1997; Dobson 2009; Hartman 2015, et cetera). However, this paper aims to show that MacIntyre's charge that management is emotivistic is worthy of reconsideration and argues that although MacIntyre's critique of management, advanced in his magnum opus After Virtue (2007 [1981]), faces a number of compelling objections, his central contention that management, broadly defined, is emotivistic is plausible. Furthermore, it goes on to suggest that this is more readily evident in the forms of management and, especially, leadership that have emerged since After Virtue was published than it was in the preceding period. Existing work on MacIntyre's relevance to business ethics has paid little attention to the history of management thought, and this paper aims to remedy that oversight.

The first section outlines MacIntyre's critique of management. MacIntyre argues that management embodies emotivism, and thus is inherently amoral and represents an "obliteration of the distinction between manipulative and non-manipulative" relation (2007, p. 30). The second section outlines and endorses two related objections to MacIntyre's account, namely that MacIntyre is wrong about the place of management in our culture, and wrong to suppose that management is inherently amoral. Indeed, a number of scholars sympathetic to and influenced by MacIntyre's ethical theory have argued for the possibility of ethical management (Beabout 2012, 2013; Beadle 2013; Dawson and Bartholomew 2003; Moore 2008, 2012, 2015, amongst others). Another component of the case against MacIntyre is the emergence of the 'cultural turn' in management thinking that occurred in the 1980s, which meant 
that management thinking moved definitively beyond MacIntyre's characterisation of it as essentially Weberian. The third section argues that the new forms of management, and in particular the renewed emphasis on leadership, especially the dominant forms-charismatic and transformational leadership - that grew out of this cultural turn embody emotivism to a greater degree than Weberian bureaucratic management could have done, and therefore MacIntyre's critique remains pertinent. MacIntyre's critique targets those who possess power and authority within organisations, and so while he focused on managers, it applies to leaders too. While these notions are interdependent and inextricably linked, there is a conceptual distinction to be made between them on the grounds that management is more closely associated with technical expertise and careful planning, and leadership is often regarded as being akin to an art form (see March and Weil 2005).

While the main aim of this paper is to support a component of one of MacIntyre's more destructive theses, the fourth section adopts a more constructive aim: that of outlining the shape of a MacIntyrean account of leadership. This section outlines the affinities between MacIntyre's political philosophy and Greenleaf's concept of servant leadership. Greenleaf's concept offers both a promising alternative to emotivistic forms of leadership and management, as well as a position which captures some of the key features of MacIntyre's work which have rarely been the focus of attention within business ethics.

\section{MacIntyre's Critique of the Manager}

Emotivism is the doctrine that moral assertions are, in essence, statements of preference. Accordingly, emotivism is sometimes known as the 'boo/hurrah' theory of morality. That is, to say ' $\mathrm{x}$ is good' is to say something like 'hurrah for $\mathrm{x}$ ' or 'I approve of $\mathrm{x}$, do so as well'. While this doctrine has roots that extend back at least as far as Hume, its modern incarnation can be dated to early twentieth century moral philosophers Ayer and Stevenson, who had been inspired by Moore's argument against ethical naturalism in his Principia Ethica (1903). Moore had argued that goodness is a simple, non-natural property that can be grasped by intuition alone. Ayer and Stevenson accepted this emphasis on intuition over reason, and the claim that goodness cannot be equated with something's being desirable, pleasurable, or conducive to flourishing. However, they further argued that when we make moral statements, we are not describing some factual state of affairs, but are rather simply expressing our emotions. As Stevenson puts it:

The emotive meaning of a word is a tendency of a word, arising through the history of its usage, to produce... affective responses in people. It is the immediate aura of feeling which hovers about a word... Roughly, then, the sentence ' $\mathrm{X}$ is good' means We like X (1944, pp. 23-24).

This entails that moral argument cannot be an attempt at rational persuasion. If our moral statements are nothing other than statements of subjective preference, then any genuine attempt at rational persuasion will be incoherent.

For MacIntyre, emotivism "entails the obliteration of any genuine distinction between manipulative and non-manipulative social relations...others are always means, never ends" (2007, pp. 23-24). When we say ' $\mathrm{X}$ is good', meaning 'We like $\mathrm{X}$ ', we may hope that assent from our audience is forthcoming; we may even hope that our statement causes that assent, but we are not offering a justification of the view that $\mathrm{X}$ is, in fact, good. However, this is not merely an innocent error restricted to academic discussions of ethics, thinks MacIntyre. Instead, while the emotivists failed to adequately account for the meaning of moral statements per se, 'murder is wrong' simply does not mean 'I dislike murder', they did successfully describe a key feature of our culture, i.e. the acceptance that there is no moral truth, and that moral claims merely reflect subjective preference.

Indeed, according to MacIntyre, we live in a distinctly emotivistic culture. This is demonstrated by the prevalence of the characters that dominate the drama of contemporary social life and shape the avenues available to agents within our society. While the Victorian age was dominated by characters such as the public school headmaster, the explorer, and the engineer, the present age is to be understood with reference to the therapist, the rich aesthete, and, most importantly for the purposes of the present paper, the manager. Characters, in MacIntyre's sense, "are social roles of a particular type because not only do they involve definitions of obligation and relationship (as do all social roles) but they also bear particular moral ideals and become representative of their social order through so doing" (Beadle 2002, p. 46); they are "those social roles which provide a culture with its moral definitions" (MacIntyre 2007, p. 31). Of the characters MacIntyre discusses, the manager, "that dominant figure on the contemporary scene" (2007, p. 74), receives the most extensive treatment:

the manager represents in his character the obliteration of the distinction between manipulative and nonmanipulative social relations ... The manager treats ends as given, as outside his scope; his concern is with technique, with effectiveness in transforming raw materials into final products, unskilled labor into skilled labor, investment into profits. (2007, p. 30)

For MacIntyre, the manager is manipulative, incapable of entering into a genuine moral argument, and matches 
means to given ends without assessing those ends. This inability to assess ends is not a matter of individual failing, but is instead a definitive feature of the managerial role.

[Managers] are seen by themselves, and by those who see them with the same eyes as their own, as uncontested figures, who purport to restrict themselves to the realms in which rational agreement is possible - that is, of course from their point of view to the realm of fact, the realm of means, the realm of measurable effectiveness. (ibid)

It is this separation of means from ends which, so MacIntyre argues, gives management its distinctively Weberian nature. According to Weber, the bureaucracies dominant in modern societies have become "increasingly more precise in calculating the methodical attainment of given practical ends" and so practical rationality is simply the "methodical attainment of a particular given practical end through the increasingly precise calculation of adequate means" (1967, p. 293). From a Weberian perspective, ends are not set by rationality, only means are, and managers - bureaucratic experts - are capable of devising these means. According to MacIntyre "Weber's thought embodies just those dichotomies which emotivism embodies, and obliterates just those distinctions to which emotivism has to be blind" (MacIntyre 2007, p. 26). Indeed, the Weberian view is committed to holding that "Questions of ends are questions of values, and on values reason is silent; conflict between rival values cannot be settled" (ibid). Weberian bureaucratic rationality is therefore unable to distinguish between manipulative and nonmanipulative social relations and unable, that is, to distinguish between merely causing agreement and rational persuasion, thereby rendering management an embodiment of emotivism.

Weberian management understands and presents itself as being a neutral, value-free, scientific expertise becoming ever more precise in its execution of its pre-ordained ends. As such, it aims to be regarded as a tool which can be used to exercise control over the bureaucracies in which it is employed. However, a final noteworthy aspect of MacIntyre's critique of management is his claim that pursuit of bureaucratic expertise is rendered yet more problematic by the fact that the kind of social scientific expertise upon which it seems to rely is impossible. Both in the decades from which MacIntyre draws his examples and the present day, the predictions issued by those social scientists who aim to posit law-like generalisations are notoriously faulty. Any managerial claims to such scientific expertise are therefore spurious.

However, MacIntyre makes a more substantial point about the ineliminability of fortuna from social life, and claims that any attempt to discover law-like generalisations in the social sciences is doomed to failure:

given the best possible stock of generalizations, we may on the day be defeated by an unpredicted and unpredictable counter-example - and yet still see no way to improve our generalizations and still have no reason to abandon them or even reformulate them. (2007, p. 93)

MacIntyre's examples of failed predictions include the fact that economic forecasts using the most advanced methods were less successful than predictions based on assuming that the next six months will resemble the last and that growth is best forecast by taking the average over the last ten years $(2007$, p. 89$)$. Moreover, the general point that "Nonexperimental social science currently is not capable of making useful, reliable, and nonobvious predictions for the effects of most proposed policy interventions" (Manzi 2012, p. 16) has, by now, been made many times. Yet, according to MacIntyre, such law-like generalisations would be necessary for managerial power and authority to be justified.

While MacIntyre is probably correct about the inherent limitations of social science, the notion that knowledge of law-like generalisations is a prerequisite of managerial effectiveness is more contentious. Indeed, there is much else in his account that is contentious, and so it is to objections facing MacIntyre's characterisation of management we now turn.

\section{Objections to MacIntyre's Account}

At the end of chapter 8 of After Virtue, MacIntyre concedes that managers and bureaucrats will likely reply to his criticisms that they are as sceptical as he is about the possibility of law-like generalisations in the social sciences but that nevertheless they are entitled to be acknowledged as experts for the more modest competences they do possess. MacIntyre's response is to acknowledge that this may be the case but to argue that "claims of this modest kind could never legitimate the possession or uses of power either within or by bureaucratic corporations on anything like the scale on which that power is wielded" (2007, p. 108). That it can be plausibly claimed that some corporations have greater power than nation states, and even that corporations now control society (Beck 2000, p. 32), provides some support for MacIntyre's contention. However, as we will see in our discussion of the emergence of leadership as an alternative to traditional forms of management, the claim to social scientific expertise is now often explicitly eschewed by those who hold positions of power within organisations. If this is so, then bureaucratic corporations do not depend on the possibility of knowledge 
of law-like generalisations in the social sciences. Before we turn our attention to leadership, however, we will consider two related objections to MacIntyre's position: that management is not regarded as an exemplar of expertise within our culture, and that management is not inherently amoral.

Large-scale bureaucratic organisations loom large over the skyline of modernity, and so those in charge of such organisations are necessarily of sociological and cultural importance. However, the evidence does not support MacIntyre's contentions about the place of the manager within our culture. McMylor suggests that MacIntyre's argument aims to be 'culturalist' rather than empirical (2015, p. 101). However, there is no sharp dichotomy between empirical and culturalist arguments: any culturalist argument will be answerable to empirical evidence pertaining to the culture in question, and it seems clear that we do not inhabit a culture that is in thrall to management.

While managers may have been held in higher esteem in the decades preceding the publication of After Virtue, consider how management is typically portrayed within contemporary culture. From The Office and Dilbert, to films such as Office Space, Horrible Bosses, and 9 to 5, to give just a few examples, management is frequently presented in popular media as incompetent, or malicious, or both. As Hendry notes, "in the popular British press the terms 'CEO' and 'fat cat' have become virtually synonymous" (2004, p. 185). Part of the appeal of these portrayals is their familiarity - they ring true to audiences. The managerial characters who inspire laughter, or embarrassment, or anger, are not presented as aberrations, but rather as being common within contemporary organisations. Such popular portrayals of management in the media and arts, although clearly not the final word on the matter, do not suggest managers are perceived as being technical experts, rationally matching means to ends with unerring efficiency. Indeed, such portrayals do not even present managers as unsuccessfully attempting to embody neutral and valuefree knowledge, which would probably be regarded as an improvement on the way in which management is in fact depicted. Business schools have not, as a matter of fact, led to management being regarded as a profession in the same way as medicine and law. While some may think this lamentable (as does Khurana 2007, for instance), and indeed calls for the professionalisation of management may be a sign that a more holistic and sophisticated conception of management is advancing, this development nevertheless suggests that MacIntyre's argument about the place of management in our culture is open to question.

Let us now turn to the second objection, the claim that management is not amoral. MacIntyre's argument is that the managerial role forces individuals to compartmentalise their judgements relative to the roles they happen to occupy and so reach very different conclusions about moral issues when acting in accordance with different roles, and thus are unable to exercise genuine moral agency (see MacIntyre 2006 for more on compartmentalisation and social roles). Again, the empirical evidence does not seem to support this argument, at least not uniformly (even if MacIntyre's case against high finance is more compelling-see MacIntyre 2015). In support of MacIntyre's argument, McMylor claims that "the recurring theme of managerial ideologies [is] the offer of pure technique, neutral and value free" (1993, p. 143). However, there is much in the literature that suggests management, rather than being a matter of mere technical expertise, is a complex mixture of skills and abilities (see, for example, Bowie and Werhane 2005). As such, management does not aim to be value free. Carroll (2001) suggests that most managers are amoral, some are immoral, and some are moral. Even if this is so, we can still conclude that management in itself is not inherently amoral, contrary to what MacIntyre's argument suggests.

Furthermore, business ethics and business ethics education are, and will continue to be, regarded as being deeply important. Evans and Weiss (2008) found that over $80 \%$ of CEOs, deans and business school faculty surveyed agree that more emphasis should be placed on ethics education in business schools. The dissatisfaction is not only felt by academic staff, however. Ditlev-Simonsen and Midttun (2011) surveyed approximately 200 students and found that they felt that managers were insufficiently motivated by ethical concerns when reasoning about corporate morality. Such surveys may highlight that management is ethically lacking, and perhaps too often prey to a tendency to prioritise bureaucratic efficiency. Furthermore, we may wonder whether respondents are simply being guided by contemporary cultural depictions of management of the kind described above. Nevertheless, the mere fact that business school staff and students feel it appropriate to address the question of managerial ethics suggests that Weber's conception of management is not dominant.

Some of the literature on management has been expressly critical of MacIntyre's argument. For example, Dobson has sought to challenge MacIntyre's position and has plausibly argued that "many managers do in fact devote non-superficial moral reflection to their role as managers" (2009, p. 46). Whatever the pressures placed on agents by managerial roles, it is hard to believe that such pressures rule out such moral reflection entirely. However, we might still wonder whether reflection is likely to be useful if the role in question demands an exploitative attitude towards subordinates.

As I noted above, a number of scholars sympathetic to MacIntyre's work have also defended the possibility of ethical management in MacIntyrean terms. In particular, Moore has sought to develop an account of managerial 
ethics based on MacIntyre's work. While Moore claims that it "seems clear that the basic tenets of [MacIntyre's] position, at least in respect of managers in business organisations under Anglo-American capitalism, remain in place" (2008, p. 495), he ultimately concludes that the claim that management is amoral is incorrect: "Are managers simply the morally-neutral efficient achievers of predetermined ends? Clearly... the answer is no" (ibid, p. 505).

If management is concerned with ethics, then it is not genuinely Weberian. At the very least, MacIntyre has exaggerated the tendency towards bureaucratic rationality within managerial thought. However, even if we have reason to remain sceptical about the ethical claims of some defenders of management, there is still much to suggest that MacIntyre's critique of management is incorrect.

The reality of fortuna, which makes knowledge of lawlike generalisations impossible in the social realm, means that on a macro-level, the kind of expertise MacIntyre argues is required to justify managerial authority is unavailable, but it also has micro-level ramifications for managers. Because of the unpredictability of the realm in which they operate, managers can easily become embroiled in complex office politics far removed from what we would expect of genuinely Weberian bureaucrats. According to Jackall's rich study of the world of corporate life, managers spend much of their time selling themselves and participating in "ongoing struggles for dominance and status" (2010, p. 208). Jackall also speaks of "continuous uncertainty and... masked conflict" (2010, p. 37) as telling features of managerial work. This portrayal may not be flattering, and certainly does nothing to advance the ethical credentials of management, but it is hard to square with MacIntyre's account which holds management to be essentially Weberian.

In light of these objections, it seems that MacIntyre's characterisation of the manager at times lapses into caricature, and therefore there are parts of his critique of management that we must simply give up. However, this is not to say that the charge of emotivism fails: managers, especially those in leadership roles, remain open to the broader charge of emotivism characteristic of management.

\section{Leadership and Emotivism}

Throughout the decades preceding the publication of After Virtue, management went through a stage we might call 'high Weberianism'. During this period, management was widely, although not universally, understood in quasi-scientific terms and regarded as being principally concerned with impersonal technique, while softer notions such as values and culture were marginalised. According to Khurana:
When salaried managers first appeared in the large corporations of the late nineteenth century, then began to proliferate, it was not obvious who they were, what they did, or why they should be entrusted with the task of running corporations. (2007, p. 3)

However, as bureaucratic management came to be accepted as normal and legitimate, the notion that managers require a kind of expertise, at least akin to that of other professionals such as medical doctors and lawyers, seems to have come to be tacitly accepted by the most influential business educational institutions. This is evident in Harold James' description of the history of business schools:

[A]s they developed in the course of the twentieth century, graduate business schools aimed at professionalising management. Especially in the United States, they were designed to give modern managers a new status that would be commensurable with a changed and enhanced role in an evolving and improving economy. The new institutions were sharply distinguished from the older commercial schools which emphasized practical and vocational training. Their founders wanted a higher prestige and a more abstract and academic education for managers who would form an elite. (2009, p. 16)

However, in this quest for professional status, business schools went beyond the standards of law schools, for instance, and sought to use quantitative social scientific methods in order to attain a veneer of academic respectability. This aim led to a technicist conception of management that resulted in what Donaldson has referred to as a "technical, scientifically inspired regimen" (1994, p. 4). As Freeman and Newkirk put it: "Implicit in much of the management discussion is a mechanical, deterministic, positivistic view of business - a financial engine controlled by the machinery of scientific management" (2009, p. 117), a view that has been criticised for its inherent 'physics envy' (Ghoshal 2005). Such a mechanistic picture of the world informs that great statement of managerial expertise, Taylor's The Principles of Scientific Management.

Despite the dominance of this mechanistic view, there was a flirtation with the notion of moulding values described in Mayo's work in the 1930s, and the subsequent 'Human Relations' movement. This movement, despite its emphasis on values, "continued to be framed by the notion that the leadership of business management... offered the best hope for employee welfare" (Grant and Mills 2006, p. 216). Furthermore, according to Johnson and Duberley:

[T] he Human Relations Movement ... embraced the idea that management could become the manipulators of social harmony in the workplace without making 
significant changes to extant bureaucratic infrastructures. (2010, p. 573)

As such, while the existence of this movement provides evidence against the claim that management is entirely unconcerned with questions of values, and so is not compatible with MacIntyre's account of management as being essentially Weberian, it does highlight the manipulative ends to which 'managerial values' can be put, and so is compatible with the broader charge of emotivism, a topic we will return to below. In any case, this value-laden approach was soon superseded by a more thoroughly bureaucratic one.

According to Witzel's study of the history of management thought, "Where there is judgement there is doubt, and one of the purposes of the new scientific approach to management that emerged after the Second World War was the elimination of doubt" (2012, p. 179), and therefore with the elimination of subjective judgement. This meant that from the 1950s "attempts to apply scientific research and concepts to management and organization increased in number and sophistication" (2012, p. 197). During this period, 'leadership' was largely neglected as a focus of scholarly attention; indeed there were even calls to abandon it as a research topic (see, for example, Greene 1977 and Miner 1975-although this view was not universal, see Zaleznik 1977).

Throughout the 1960s and most of the 1970s, not only did corporate culture not occupy a central place in management scholarship and practice, it was even something of a taboo subject (Peters and Waterman 1982, p. 105). However, since a 'cultural turn' in management thinking in the early 1980s, this bureaucratic Weberian conception of management is no longer dominant. During recent decades, it has become commonplace for the management and organisational literature to claim that work organisations ought to be, and increasingly are, post-bureaucratic and 'flexible'. The Weberian conception of management and organisations has not disappeared entirely, after all it is hard to deny that business culture tends to "suppress difficult questions of values" (Hendry 2004, p. 177), and some have argued that a process of re-bureaucratisation has occurred (Hodgson 2004), but where it persists it is often the subject of considerable dissent:

What is killing us is the illusion of control: that things can be predictable, consistent and forever under control. What is also killing us is that followers require their leaders to be in control, on top of things, and to take the blame when things go wrong. Nearly all the new management programmes on TQM, reengineering, right-sizing, just-in-time, this or that, are really old wine in new bottles - more efforts to design control systems that ask the workers to try harder; do better and be even more productive. (April et al 2000, p. 1)

If the conception of the manager-as-bureaucratic-expert was dominant in the middle of the twentieth century, in the past few decades, the paradigm has shifted significantly. MacIntyre once claimed that Marx's analysis of capitalism holds true for the period 1848 to 1929 (1970, p. 43), and although it seems likely that truly neutral, amoral management was never a practical reality, it is tempting to similarly claim that MacIntyre's account of management broadly holds true for the period from 1945 to around 1980, but not beyond.

Since then, it has become common for scholars to highlight management practices which clearly diverge from the Weberian paradigm. For instance, Gimpl and Dakin draw parallels between managers' and leaders' forecasting techniques and ancient superstitious fortunetelling rites used to determine the best hunting grounds and which gave random answers (1984, pp. 125-137). Such rites were useful in that they enabled people to resist the temptation to use the same hunting grounds time and again, thus preventing over-hunting in those areas. Somewhat analogously, management forecasting is useful in that it provides confidence in times of uncertainty, even if the forecasts themselves are unreliable. These rites are clearly not explicable in solely Weberian terms, and thus it has become harder and harder to regard management as a realm of impersonal technique.

Indeed, according to numerous commentators, including influential management theorist Henry Mintzberg, in the latter part of the twentieth century, the concept of 'leadership' overtook the concept of 'management', and indeed "pushed it off the map" (Mintzberg 2009, p. 1). Arnold et al note that early management research focused on the leader-as-tactician whereas more recent studies focus on the leader-as-inspirational-figure (2005, p. 487). Furthermore, Hollway notes that in recent literature "the ghost of managerial leadership has come back to haunt the field" and that according to this literature "managers are not needed in organizations, only leaders" (1991, p. 142).

In what ways does leadership differ from management? While Mintzberg (2009) has noted that it is, in practice, impossible to fully separate management and leadership, there are some important conceptual differences. Kotter (1990) observes that management is about coping with complexity and leadership about coping with change; leaders focus on 'creating a vision' whereas managers will 'develop a plan'. Adair (2009) suggests that leadership is an art form, whereas management is a science, and that leadership is associated with personality and vision, management with structure, routine, and methods. Personal attributes associated with leadership, such as creativity, are 
the 'added value' that leadership brings to management (Adair 2005, p. 62).

The difference is especially pronounced in the case of leadership theories which foreground charisma, vision, and inspiration, such as transformational and charismatic leadership. A comprehensive survey of the leadership literature would no doubt reveal various other theories and models which possess some affinities with the theories covered here, and which may or may not be susceptible to critique as emotivistic. However, these two accounts of leadership have dominated the field to the extent that they "have eclipsed and possibly maybe stunted" other models (Antonakis 2012, p. 257). Although we can distinguish between charismatic and transformational leadership (as well as between competing charismatic and transformational models), they are often taken as a pair, and indeed as they became dominant were characterised together as the 'new leadership' by Bryman (1992). For present purposes, we need only note that they are broadly similar, especially insofar as they focus on affective responses and aim at persuasion without rational argument.

Leadership in this sense is not an intrinsically scientific concept, as MacIntyre takes management to be. Good leaders may require certain abilities, but not the bureaucratic expertise of the Weberian manager. The knowledge and charisma required to be an effective leader are not the same as the impersonal knowledge of law-like generalisations once thought to be required for bureaucratic expertise, and leadership is often expressly concerned with questions of ethics and values. Quite clearly then, dominant forms of leadership do not answer to MacIntyre's description of amoral technocratic management-the matching of means to exogenously given ends.

However, this does not mean that modern forms of leadership are not embodiments of emotivism, nor does it mean that MacIntyre's argument does not apply to leaders. In After Virtue, MacIntyre makes it clear that his argument pertains to those who "achieve power or authority" (2007, p. 107) within organisations, and so applies to leaders as much as managers.

In any case, the charge of emotivism is what concerns us here, and it seems that the dominant forms of leadership are more nakedly emotivistic than Weberian forms of bureaucratic management. Recall the central features of emotivism: morality is regarded as being non-rational, it holds that goodness can be grasped by intuition alone, moral statements are simply statements of preference, and so causing others to accept one's preferences is not distinguishable from persuading them of the rationality of your view. Moral argument is therefore side-lined in favour of non-rational forms of persuasion.

While scientific management could justly be regarded as manipulative in that it saw workers as tools to be expertly controlled, the dominant forms of leadership are manipulative in that they attempt to use charisma and inspiration in place of rational persuasion. Scientific management inherited some degree of fallibilism from modelling itself on the natural sciences, and so could reject falsified hypotheses (though in reality management ideas are often replaced before their adequacy has been determined-as Ciulla (2000) points out, the life-cycle of management fads has shrunk from ten years to one year). By contrast, leadership seems to be even more emotivistic than the older bureaucratic style of management because it is less answerable, even in principle, to empirical evidence and therefore to possible counter-example.

This is clear in Weber's own work on charisma. For Weber, charisma in leaders referred to "specific gifts of the body and spirit not accessible to everybody" (1968, p. 19). Charismatic authority, unsuited in Weber's mind to the tasks of modernity, is quite different from bureaucratic authority, and at the core of charisma is an emotional appeal whose "attitude is revolutionary and trans-values everything; it makes a sovereign break with all traditional or rational norms" $(1968$, p. 24). This break with rational norms is what signals the affinity between modern forms of leadership and emotivism. Leaders attempt to change people's attitudes by provoking an affective response, and through the 'aura of feeling which hovers' around their words. Thus, the changes effected, unlike changes brought about through rational argument, will not be the result of deliberation and debate. As one manager in Kunda's study of hi-tech firms put it:

Power plays don't work. You can't make 'em do anything. They have to want to. So you have to work through the culture. The idea is to educate people without knowing it. Have the religion and not know how they got it. (1992, p. 5)

When displays of power will not suffice, non-rational manipulation through management of culture is required. Rational persuasion, note, is not considered as a primary option. Instead, ever more rhetorically satisfying ways of saying 'hurrah for $\mathrm{x}$ ' are devised.

This emphasis on the non-rational clearly emerges from the literature on the dominant forms of leadership. Bono and Ilies show that "both leaders' positive emotional expressions and follower mood influenced ratings of leader effectiveness and attraction to the leader" (2006, p. 317). Cherulnik et al (2001) suggest that charisma is contagious, undermining any requirement for rational persuasion. Sashkin (1988) notes that leaders rely more on intuition than intellect. According to Bass, inspirational leadership "employs or adds nonintellectual, emotional qualities to the influence process" (1985, p. 63). Each of these features highlights the conceptual connection between the doctrine of emotivism and contemporary forms of leadership. While 
they clearly do not aim to be neutral and value free, their focus on achieving their ends through effective means other than rational persuasion suggests they share something of the instrumentalism that was characteristic of bureaucratic management.

Antonakis found that "Charismatic leaders communicate symbolically, use imagery, and are persuasive in communicating a vision that promises a better future. In this way, they create an intense emotional attachment with their followers" (2012, p. 265). Here assent is merely caused by the alluring rhetoric; it is not brought about through rational persuasion. The key features of charismatic leadership, such as use of metaphor, being a good story teller, and mastery of rhetoric, all suggest the same thing: that the dominant forms of leadership are inherently emotivistic. Even Burns' (1978) formulation of transformational leadership, which set itself the noble aim of encouraging leaders and followers to attain higher levels of morality, arguably "collapses into a transactional process of emotionally charged ideological exchange" (Allix 2000, p. 18). So, it seems that the dominant forms of leadership which have emerged since MacIntyre published his critique of management are susceptible to that critique, albeit for reasons different from those MacIntyre offered. However, in the following section, we will turn to consider a form of leadership which is far from dominant, and which might survive MacIntyre's charge.

\section{A MacIntyrean Leadership?}

MacIntyre himself is sceptical about the possibility of ethical business and management, and indeed about the possibility of the good life under capitalism more generally. Indeed, given his critique of management and the argument developed here, that it also pertains to leadership, we might wonder whether MacIntyre's work has any relevance to a more positive account of leadership. However, like other business ethicists inspired by MacIntyre's work (e.g. Beabout 2012, 2013; Beadle 2013; Dawson and Bartholomew 2003; Moore 2008, 2012, 2015), we are able to use MacIntyre's work against him in this regard.

If the dominant forms of leadership are susceptible to MacIntyre's charge of emotivism, what would an account of leadership compatible with MacIntyre's moral philosophy look like? There is much in MacIntyre's work as a whole which would be essential to a comprehensive description of MacIntyrean leadership, in particular his account of practices-rich, complex activities which serve as the foundation of our moral education (see MacIntyre 2007 , p. 187). However, such a comprehensive treatment is beyond the scope of the present essay; instead, we will examine the basic shape a MacIntyrean account of leadership must take. Sinnicks (2014) has suggested that
MacIntyre's political philosophy holds the key to successful application of his work in business ethics, and this section aims to build on this suggestion.

Like Aristotle, MacIntyre defends the anti-elitist claim that ethics and politics are inseparable. However, MacIntyre argues that contemporary politics is unacceptably exclusive, and treats the electorate as a passive majority which is only to be mobilised at periodic intervals. Instead, we need to foster a rival conception of politics which sets itself three key aims: to sustain local communities, facilitate shared deliberation, and serve the common good (MacIntyre 1999). While most business ethicists influenced by MacIntyre have focused on the distinctly ethical part of his work, it turns out that it is predominantly MacIntyre's political philosophy which is most relevant to the question of ethical management and leadership. The good manager or leader will, on this view, be principally concerned to sustain the workplace community, or communities, in question, to facilitate common deliberation within those communities, and ultimately to serve the common good (for an insightful discussion of the challenges involved in pursuing such goods within organisations, see Moore and Beadle 2006).

What is most attractive about MacIntyre's work, both in its own right and as it pertains to leadership and management, is its emphasis on moral education and flourishing. Community members are perfected by their engagement in the practice of politics, and its focus on sustaining human relationships. This political theory is deeply at odds with our distinctively modern conception of the nation state, but nevertheless it has consequences for management and leadership which may be practically applicable without overturning the existing order.

One of the most striking features of MacIntyre's political philosophy is his claim that "insofar as human beings have the capacity to become good, they also have the capacity to exercise the prudence of a ruler" (2006, p. 49). This implies that those who do in fact become rulers have no special capacity, a challenge to Weberian managers and charismatic leaders alike (as well as to the political elites in modern liberal democracies). Therefore, "those who arrogate to themselves an exclusive, professionalised authority of a certain kind by that very act of arrogation discredit their own claims to legitimate authority" (2006, p. 51). This is because such an attitude is liable to prevent the governed from learning from one another and therefore from effectively deliberating. In essence, self-professed elitists underestimate the abilities of ordinary people to such a degree as to make the claimants incompetent as governors of those ordinary people. One way in which this incompetence may manifest itself is by preventing managers and leaders from achieving the balanced perspective required to make purposeful, moral decisions, which will 
necessarily be at odds with all forms of emotivistic manipulation.

What this suggests is that leadership and management must be deeply democratic - to a degree which contemporary democratic governments usually are not-and involve the equal and active participation of all relevant parties, if it is to deliver on its moral potential. However, in practice, there are several reasons to think this aim may be worthy but impossible. Firstly, even if we aspire to the level of democratic participation MacIntyre advocates, efficiency may require someone to be answerable for decisions, which would pose significant challenges for any attempt to establish management by sortition, the process of random selection used to appoint officials in Athenian democracy. Secondly, even if MacIntyre is right, it may still be the case that not everyone successfully develops his or her potential for rule, for whatever reason. Thirdly, not everyone is interested in workplace democracy or aspires to a position of influence; some regard work merely as a means to other ends. So, for now we will assume that some kind of established and formally hierarchical leadership is, at least in the majority of cases, desirable, and that we should be concerned with finding the most ethically ameliorative account of leadership. Such an account will be modelled on MacIntyre's political philosophy even though it will inevitably fall short of his ideal.

Based on the central tenets of MacIntyre's account of politics, the concept of servant leadership, initially espoused by Greenleaf in the 1970s, is a most promising candidate for an account of ethical leadership. Beabout has noted that Greenleaf's work influenced Block's account of stewardship which informs Beabout's own MacIntyrean account of management (2013, pp. 175-176). While there is "still no consensus about a theoretical framework of servant leadership" (Van Dierendonck 2011, p. 1229) more generally, it seems that Greenleaf's concept provides a useful basis for a broadly MacIntyrean account of leadership, and in turn can be usefully supplemented by MacIntyre's arguments.

Servant leadership is based on the idea that, as its name suggests, a leader's first priority ought to be to serve others. According to Greenleaf, under servant leaders, employees can become "healthier, wiser, more autonomous and more likely themselves to become servants" (1977, p. 6). This echoes MacIntyre's claim that in a rational polity, all must learn to rule and be ruled (2011, pp. 13-14), and adheres to the general emphasis on serving the common good found throughout his political writings. This view holds that true leadership is allocentric in a way that the dominant forms of leadership could not be, and as such servant leadership is not open to the charge of emotivistic manipulation levelled at bureaucratic management and charismatic and transformational leadership above. Servant leadership does not set out to cause assent (to ' $\mathrm{X}$ is good', for instance), and so does not need to provoke an emotive response through rhetorical means ('hurrah for X').

In the absence of law-like generalisations, the servant leader must recognise the fallibility of his or her judgements. Servant leadership requires humility, and for leadership to reflect the community in which it is situated (as Grint (2005, p. 101) suggests for leadership as a whole). Servant leadership is thus a moral position as much as an account of organisational practice, and requires leaders to put the well-being of 'followers' before other goals. According to Sendjaya et al (2008), servant leaders practice voluntary subordination in attending to the legitimate needs of others. The intended contrast here is with "self-seeking leaders who serve others only when it is convenient or personally advantageous" to do so (Sendjaya et al 2008, p. 406). The humility implied here is in stark contrast to the dominant leadership paradigm. According to Tourish and Pinnington, many mainstream business leaders "develop a monomaniacal conviction that there is one right way of doing things, and believe they possess an almost divine insight into reality" (2002, p. 147), and thus lack the humility required by servant leadership. Given the emphasis on serving others, the threat of this egoistic delusion is clearly reduced for servant leaders. Lee and Zemke state, "The [servant]-leader's belief system says he or she is no better than those who are led" (1993, p. 86), an explicit rejection of the claim to "an exclusive, professionalised authority" MacIntyre warns against. This again highlights the affinities between Greenleaf's concept of leadership and MacIntyre's political philosophy.

Smith et al. (2004) posit that the leader's motivation is what distinguishes servant leadership from charismatic leadership. Motivation is an especially important factor as it changes the relationship with those being led. Such an emphasis on motivation is an important characteristic, and arguably an advantage, of virtue ethics in general, which again highlights servant leadership's proximity to MacIntyre's philosophy. Indeed, one of the main criticisms of servant leadership is that it describes a philosophy rather than a measurable leadership style (though see Van Dierendonck 2011 for a review of the empirical work that has been carried out).

Greenleaf regarded his approach to have a spiritual dimension, and servant leadership seems to require a change in a person's character (Marshall 2003), suggesting that servant leadership is indeed a philosophical position as much as a leadership style. However, when viewed through the prism of MacIntyre's moral theory, this apparent weakness reveals itself to be a strength. On MacIntyre's view, while there is a core conception of virtue, and while there is a set of virtues-justice, courage, and honesty (2007, p. 191) - that are universal goods and found, to 
greater or lesser degrees, in all human societies, the exercise of the virtues is highly context-dependent. For example, courage is the virtue of being willing to risk harm in pursuit of some good, but members of different cultures and social groups may give different answers to the question 'what exactly is the mean between cowardice and rashness?' Therefore, an account of courage which aims to stipulate precisely what courage is and is not is liable to be blind to hitherto unexpected counter-examples and unforeseen social and cultural conditions. Similarly, an apt implementation of servant leadership will vary with circumstances, and with the particular ends and agents being served. As such, it would be unwise to seek to stipulate the necessary array of essential features that would make it a discrete measurable leadership style. Moreover, it is inherently difficult to measure the virtues (see Robson 2015). In any case, measurable leadership styles seem to have little advantage even when it comes to achieving set ends. Alimo-Metcalfe and Alban-Metcalfe, who have also argued for the superiority of servant leadership over transformational models (see their 2005), report that studies which have attempted to find a correlation between leadership style and outcome (e.g. productivity, stress, absenteeism) actually found no such correlation (2002, p. 304).

Another possible response to this charge is that, given the apparently cyclical pattern of corporate scandal, followed by public outcry, followed by a call for greater emphasis on business ethics, and followed by a return to normal and then a fresh round of corporate scandal (Abend 2014 , p. 19), it is perhaps time for a position that gives moral philosophy, and the character traits associated with the ideal of service, priority over other considerations. Servant leadership may therefore be just the definitive break with the instrumentalism characteristic of Weberian management that is needed in light of the recurrence of breakdowns in business ethics. That is not to say that servant leadership is to be seen as a panacea for problems like corruption and cronyism, but that such ethical problems give us good reason to be less resistant to what may initially strike us as a counter-intuitive or excessively demanding account of management or leadership.

There are other challenges which can be levelled at servant leadership. For instance, the claim that servant leaders are naïve (Johnson 2001), and as such can be seen as weak or easily manipulated (Bowie 2000). No approach is entirely immune to risk, and a servant leader must develop the intelligence to detect attempts at manipulation as well as the courage to refuse to submit to them, which may require taking stands which those led incorrectly believe go against their interests. However, as servant leadership is a philosophical and ethical position as much as a leadership style; it seems well-placed to take on such distinctly ethical counsel. Bowie and Werhane (2005) raise the possibility of servant leaders falling prey to servility. However, 'service', in the sense intended, is to be seen as a mean between servility and domination. While it is true that the dominant forms of leadership run less risk of falling into servility than does servant leadership, this is only at the expense of enhancing the risk of collapsing into the other extreme.

A related but, according to Bowie and Werhane, more pressing worry is that the desire to serve produces workaholics who neglect their personal lives. MacIntyre's remarks about patience are instructive here:

Patience is the virtue of waiting attentively without complaint, but not of waiting thus for anything at all. To treat patience as a virtue presupposes some adequate answer to the question: waiting for what? (2007, p. 202)

On such a view, patiently waiting for something that is not worthwhile would be a mistake. Likewise, patiently waiting for something that is worthwhile but doing so at the expense of something more important would also be a mistake. A similar point can be made about service: a commitment to serving others is a good, but it ought to be subordinate to greater goods. So while the ethical core of servant leadership gives rise to a tendency to sacrifice the self in order to serve the community of followers, a prudent leader (i.e. one who also wishes to live to serve another day) will not do so. Furthermore, a neglect of one's personal life seems to be an equal threat to versions of leadership which give rise to the monomania Tourish and Pinnington warned of above. There are also, no doubt, other challenges which may be levelled at servant leadership. However, our discussion about its suitability as a basis of a MacIntyrean account of leadership has aimed to show that it has much to recommend it and that it is wellplaced to avoid the charge of emotivism which threatens the dominant accounts of leadership.

\section{Conclusion}

Having outlined MacIntyre's critique of management, we saw above that a number of details of that critique are untenable given the place management occupies in our culture and the concern with questions of values displayed by managers. Nevertheless, the central charge of emotivism holds for the dominant transformational and charismatic forms of leadership, which have emerged in the decades since After Virtue was first published. Such forms of leadership possess a number of features of emotivism, such as the emphasis on affective response and non-rational persuasion. Despite this emotivism, and despite 
MacIntyre's general opposition to the institutions of modernity, there is scope to draw on MacIntyre's political philosophy in order to outline an account of leadership, and Greenleaf's conception of servant leadership is a promising place to start due to its compatibility with MacIntyre's political philosophy.

It is, of course, possible to support servant leadership with reference to a variety of other theoretical positions, such as personalism (Whetstone 2002), and perhaps other varieties of Aristotelian virtue ethics (as outlined by Foot 2001; Annas 2011 and so on) which are disposed to be critical of manipulative modes of moral engagement. Similarly, there may be other forms of leadership, e.g. engaging, critical, authentic, and so on, which, like servant leadership, are compatible with attempts to rationally persuade followers, and which could be integrated with servant leadership on account of this affinity with virtue ethics. However, such a complete map of the terrain is beyond the scope of the present paper, and may instead be a fruitful aim for future research.

The appropriate scope of servant leadership is another topic worthy of further consideration. Like any conception of leadership, servant leadership is not suited to all situations. The military commander who, in the heat of the battle, finds him or herself lost in thought about how to serve the needs of those led leads badly. Certain contexts call for an approach based on servant leadership more obviously than others, and establishing which organisational contexts are conducive to servant leadership, and how servant leaders can sustain such contexts in the face of external pressures, is another possible area for future research. The various, and at times apparently conflicting, interests of stakeholders present servant leaders and wouldbe servant leaders with serious challenges which require a good deal of moral insight and sensitivity to adequately deal with.

Acknowledgements I would like to thank Daniel Pointon and three anonymous reviewers for Journal of Business Ethics for their comments on previous versions of this paper.

Open Access This article is distributed under the terms of the Creative Commons Attribution 4.0 International License (http://crea tivecommons.org/licenses/by/4.0/), which permits unrestricted use, distribution, and reproduction in any medium, provided you give appropriate credit to the original author(s) and the source, provide a link to the Creative Commons license, and indicate if changes were made.

\section{References}

Abend, G. (2014). The moral background. Princeton, NJ: Princeton University Press.

Adair, J. (2005). How to grow leaders: The seven key principles of effective leadership development. London: Kogan Page.
Adair, J. (2009). Not bosses, but leaders: How to lead the way to success (3rd ed.). London: Kogan Page.

Alimo-Metcalfe, B., \& Alban-Metcalfe, J. (2002). Leadership. In P. Warr (Ed.), Psychology at work. London: Penguin.

Alimo-Metcalfe, B., \& Alban-Metcalfe, J. (2005). Leadership: Time for a new direction? Leadership, 1(1), 51-71.

Allix, N. M. (2000). Transformational leadership: Democratic or despotic? Education Management \& Administration, 28(1), $7-20$.

Annas, J. (2011). Intelligent virtue. Oxford: Oxford University Press.

Antonakis, J. (2012). Transformational and charismatic leadership. In D. V. Day \& A. Antonakis (Eds.), The nature of leadership (2nd ed., pp. 256-288). London: Sage.

April, K. A., Macdonald, R., \& Vriesendorp, S. (2000). Rethinking leadership. Kenwyn: UCT Press.

Arnold, J. M., Silvester, J., Patterson, F., Cooper, C. L., Robertson, I. T., \& Burnes, B. (2005). Work psychology (4th ed.). Harlow: Pearson Education.

Bass, B. M. (1985). Leadership and performance beyond expectations. New York: Free Press.

Beabout, G. (2012). Management as a domain-relative practice that requires and develops practical wisdom. Business Ethics Quarterly, 22(2), 405-432.

Beabout, G. (2013). The character of the manager. Basingstoke: Palgrave Macmillan.

Beadle, R. (2002). The misappropriation of MacIntyre. Philosophy of Management, 2(2), 45-54.

Beadle, R. (2013). Managerial work in a practice-embodying institution: The role of calling, the virtue of constancy. Journal of Business Ethics, 113(4), 679-690.

Beck, U. 2000. Brave new world of work (P. Camiller, Trans.). Malden, MA: Blackwell.

Bono, J. E., \& Ilies, R. (2006). Charisma, positive emotions and mood contagion. The Leadership Quarterly, 17(4), 317-334.

Bowie, N. E. (2000). Business ethics, philosophy, and the next 25 years. Business Ethics Quarterly, 10(1), 7-20.

Bowie, N. E., \& Werhane, P. H. (2005). Management ethics. Oxford: Blackwell.

Brewer, K. B. (1997). Management as a practice: A response to Alasdair MacIntyre. Journal of Business Ethics, 62(2), 825-833.

Bryman, A. (1992). Charisma and leadership in organizations. London: Sage.

Burns, J. M. (1978). Leadership. New York: Harper and Row.

Carroll, A. B. (2001). Models of management morality for the new millenium. Business Ethics Quarterly, 11(2), 365-371.

Cherulnik, P. D., Donley, K. A., Wiewel, T. S. R., \& Miller, S. R. (2001). Charisma is contagious: The effect of leaders' charisma on observers' affect. Journal of Applied Social Psychology, 31(10), 2149-2159.

Ciulla, J. B. (2000). The working life: The promise and betrayal of modern work. New York: Times Business Books.

Dawson, D., \& Bartholomew, C. (2003). Virtues, managers and business people: Finding a place for MacIntyre in a business context. Journal of Business Ethics, 48(2), 127-138.

Day, D. V., \& Antonakis, J. (2012). The nature of leadership (2nd ed.). Thousand Oaks, CA: Sage.

Ditlev-Simonsen, C. D., \& Midttun, A. (2011). What motivates managers to pursue corporate responsibility? A survey among key stakeholders. Corporate Social Responsibility and Environmental Management, 18(1), 25-38.

Dobson, J. (2009). Alasdair MacIntyre's Aristotelian business ethics: A critique. Journal of Business Ethics, 86, 43-50.

Donaldson, T. J. (1994). Introduction. In T. J. Donaldson \& R. E. Freeman (Eds.), Business as a humanity. New York: Oxford University Press. 
Evans, F. J., \& Weiss, E. J. (2008). Views on the importance of ethics in business education. Advancing Business Ethics Education, 10, 43-66.

Ferrero, I., \& Sison, A. J. G. (2014). A quantitative analysis of authors, schools and themes in virtue ethics articles in business ethics and management journals (1980-2011). Business Ethics: A European Review, 23(4), 375-400.

Foot, P. (2001). Natural goodness. Oxford: Oxford University Press.

Freeman, R., \& Newkirk, D. (2009). Business as a human enterprise. In S. Gregg \& J. R. Stoner (Eds.), Rethinking business management: Examining the foundations of business education (pp. 139-143). Princeton, NJ: ISI.

Ghoshal, S. (2005). Bad management theories are destroying good management practices. Academy of Management Learning \& Education, 4(1), 75-91.

Gimpl, M., \& Dakin, S. (1984). Management and magic. California Management Review, 27(1), 125-136.

Grant, J. D., \& Mills, A. J. (2006). The quiet Americans: Formative context, the Academy of Management leadership, and the management textbook, 1936-1960. Management and Organizational History, 1(2), 201-224.

Greene, C. N. (1977). Disenchantment with leadership research: Some causes, recommendations, and alternative directions. In J. G. Hunt \& L. L. Larson (Eds.), Leadership: The cutting edge (pp. 57-67). Carbondale: Southern Illinois University Press.

Greenleaf, R. K. (1977). Servant leadership. New York: Paulist Press.

Grint, K. (2005). Leadership: Limits and possibilities. Basingstoke: Palgrave MacMillan.

Hartman, E. M. (2015). Virtue in business ethics: Conversations with Aristotle. Cambridge: Cambridge University Press.

Hendry, J. (2004). Between enterprise and ethics. Oxford: Oxford University Press.

Hodgson, D. (2004). Project work: The legacy of bureaucratic control in the post bureaucratic organization. Organization, 11(1), 81-100.

Hollway, W. (1991). Work psychology and organizational behaviour: Managing the individual at work. London: Sage.

Jackall, R. (2010). The world of corporate managers (20th anniversary edition). Oxford: Oxford University Press.

James, H. (2009). The ethics of business life: Some historical reflections. In S. Gregg \& J. R. Stoner (Eds.), Rethinking business management: Examining the foundations of business education. Princeton, NJ: Witherspoon Institute.

Johnson, C. (2001). Meeting the ethical challenges of leadership. Thousand Oaks, CA: Sage.

Johnson, P., \& Duberley, J. (2011). Anomie and management studies: Reappraising Durkheim. Organization, 18(4), 563-584.

Khurana, R. (2007). From higher aims to hired hands: The social transformation of American Business Schools and the unfulfilled promise of management as a profession. Princeton: Princeton University Press.

Kotter, J. P. (1990). How leadership differs from management. New York: Free Press.

Kunda, G. (2006). Engineering culture: Control and commitment in a high-tech corporation (2nd ed.). Philadelphia, PA: Temple University Press.

Lee, C., \& Zemkis, R. (1993). The search for spirit in the workplace. Training, 30, 21-28.

MacIntyre, A. (1970). Marcuse. London: Fontana.

MacIntyre, A. (1999). Dependent rational animals. Chicago: Open Court.

MacIntyre, A. (2006). Selected essays (Vol. 2). Cambridge: Cambridge University Press.

MacIntyre, A. (2007). After virtue (3rd ed.). London: Duckworth.

MacIntyre, A. (2011). How Aristotelianism can become revolutionary: Ethics, resistance, utopia. In P. Blackledge \& K. Knight (Eds.), Virtue and politics (pp. 3-7). Notre Dame, IN: Dame University Press.
MacIntyre, A. (2015). The irrelevance of Ethics. In A. Bielskis \& K. Knight (Eds.), Virtue and economy: Essays on morality and markets (pp. 7-21). Farnham: Ashgate.

Manzi, J. (2012). Uncontrolled: The surprising payoff of trial-anderror for business, politics, and society. New York: Basic Books.

March, J. G., \& Weil, T. (2005). On leadership. Oxford: Wiley.

Marshall, T. (2003). Understanding leadership. Grand Rapids, MI: Baker Books.

McMylor, P. (1993). Alasdair MacIntyre: Critic of modernity. London: Routledge.

McMylor, P. (2015). No place to hide for the moral self: bureaucratic individualism and the fate of ethics in modernity. In A. Bielskis \& K. Knight (Eds.), Virtue and economy essays on morality and markets. Farnham: Ashgate.

Miner, J. B. (1975). The uncertain future of the leadership concept. An overview. In J. G. Hunt \& L. L. Larson (Eds.), Leadership frontiers (pp. 197-208). Kent, OH: Kent State University Press.

Mintzberg, H. (2009). Managing. San Francisco: Berrett-Koehler.

Moore, G. E. (1903). Principia ethica. Mineola, NY: Dover.

Moore, G. (2008). Re-imagining the morality of management: A modern virtue ethics approach. Business Ethics Quarterly, 18(4), 483-511.

Moore, G. (2012). The virtue of governance, the governance of virtue. Business Ethics Quarterly, 22(2), 293-318.

Moore, G. (2015). Corporate character, corporate virtues. Business Ethics: A European Review, 24(S2), 99-114.

Moore, G., \& Beadle, R. (2006). In search of organizational virtue in business: agents, goods, practices, institutions and environments. Organization Studies, 27(3), 369-389.

Peters, T., \& Waterman, R. H. (1982). In search of excellence. New York: Harper \& Row.

Robson, A. (2015). Constancy and integrity: (Un) measurable virtues? Business Ethics: A European Review, 24(S2), 115-129.

Sashkin, M. (1988). The visionary principal: School leadership for the next century. Education and Urban Society, 20(3), 239-249.

Sendjaya, S., Sarros, J. C., \& Santora, J. C. (2008). Defining and measuring servant leadership behaviour in organizations. Journal of Management Studies, 45, 402-424.

Sinnicks, M. (2014). Practices, governance and politics: Applying MacIntyre's ethics to business. Business Ethics Quarterly, 24(2), 229-249.

Smith, B. N., Montagno, R. V., \& Kuzmenko, T. N. (2004). Transformational and servant leadership: Content and contextual comparison. Journal of Leadership and Organizational Studies, 10(4), 80-91.

Stevenson, C. L. (1944). Ethics and language. New Haven, CT: Yale University Press.

Taylor, F. W. (1911). The principles of scientific management. London: Harper and Brothers.

Tourish, D., \& Pinnington, A. (2002). Transformational leadership, corporate cultism, and the spirituality paradigm: An unholy trinity in the workplace? Human Relations, 55(2), 147-172.

Van Dierendonck, D. (2011). Servant leadership: A review and synthesis. Journal of Management, 37(4), 1228-1261.

Weber, M. (1967). The social psychology of world religions. In H. Gerth \& C. W. Mills (Eds.), From max weber: Essays in sociology. London: Routledge.

Weber, M. (1968). The prophet. In S. N. Eisenstadt (Ed.), Max Weber on charisma and institutional building. Chicago: The University of Chicago Press.

Whetstone, J. T. (2002). Personalism and moral leadership: The servant leader with a transforming vision. Business Ethics: A European Review, 11(4), 385-392.

Witzel, M. (2012). A history of management thought. London: Routledge.

Zaleznik, A. (1977). Managers and leaders: Are they different? Harvard Business, 55(5-6), 67-78. 